\title{
Development of Anti-Acne Film from Bio-Cellulose Incorporating Punica granatum Peel Extract
}

\section{Preeyawass PHIMNUAN ${ }^{1}$, Swanya YAKAEW ${ }^{1}$, Atchariya YOSBOONRUANG ${ }^{2}$, Witoo LUANGBUDNAK ${ }^{3}$, Francois GRANDMOTTET ${ }^{4}$ and Jarupa VIYOCH ${ }^{1, *}$}

\author{
${ }^{1}$ Department of Pharmaceutical Technology, Faculty of Pharmaceutical Sciences and Center of \\ Excellence for Innovation in Chemistry, Naresuan University, Phitsanulok 65000, Thailand \\ ${ }^{2}$ Department of Microbiology, Faculty of Medical Sciences, University of Phayao, \\ Phayao 56000, Thailand \\ ${ }^{3}$ Department of Pharmacy Practice, Faculty of Pharmaceutical Sciences, Naresuan University, \\ Phitsanulok 65000, Thailand \\ ${ }^{4}$ Department of Biochemistry, Faculty of Medical Science, Naresuan University, \\ Phitsanulok 65000, Thailand
}

('Corresponding author's e-mail: jarupav@nu.ac.th)

Received: 27 November 2017, Revised: 1 May 2018, Accepted: 6 June 2018

\begin{abstract}
The aim of this study was to formulate bio-cellulose film incorporating Punica granatum (pomegranate) peel extract for application as anti-acne product. The dried pomegranate peels were extracted by water $\left(\mathrm{PPE}_{\mathrm{water}}\right), 50 \%\left(\mathrm{PPE}_{50 \mathrm{E}}\right), 70 \%\left(\mathrm{PPE}_{70 \mathrm{E}}\right)$ or $95 \%\left(\mathrm{PPE}_{95 \mathrm{E}}\right)(\mathrm{v} / \mathrm{v})$ ethanol. The extracts were total phenolic content (TPC) and free radical scavenging activity. $\mathrm{PPE}_{50 \mathrm{E}}$ had highest TPC $\left(55.95 \pm 1.44 \mathrm{gGAE} / 100 \mathrm{~g}\right.$ of dried peel extract), highest free radical scavenging activity with $\mathrm{IC}_{50}$ of $18.77 \pm 1.73 \mu \mathrm{g} / \mathrm{ml}$ and exerted the activity of bactericidal against Staphylococcus aureus, Staphylococcus epidermidis and Propionibacterium acne (P. acne). The $\mathrm{PPE}_{50 \mathrm{E}}$ was selected for formulating anti-acne bio-cellulose (BC) film. The BC film prepared from bacteria Acetobacter xylinum. It showed a strong film with the tensile strength in range of $5-15 \mathrm{MPa}$ and the elongation at break about $5 \%$. The simple soaking method was used to combine BC with 5 or $10 \mathrm{mg} / \mathrm{ml}$ of PPE $50 \mathrm{E}$. By the SEM, the assemble nanofibrils and the layer structure of the BC combining with the $\mathrm{PPE}_{50 \mathrm{E}}(\mathrm{BCP})$ was found. The BCP had higher tensile strength and lower elongation at break than the $\mathrm{BC}$. The $\mathrm{BCP}$ at wet state showed a soft and flexible film. The anti-bacterial efficacy of the BCP against tested bacteria was observed, according to the disc diffusion assay. The $P$. acne inhibition zones of the BCP at the concentration of 5 and $10 \mathrm{mg} / \mathrm{ml} \mathrm{were}$ 27.7 and $35.5 \mathrm{~mm}$ which closed to the clindamycin $(45.5 \mathrm{~mm})$ as positive control. From the remarkable results, the $\mathrm{BCP}$ is interestingly natural device for acne treatment.
\end{abstract}

Keywords: Pomegranate peel extract, Bio-cellulose, Acetobactor xylinum, Staphylococcus aureus, Staphylococcus epidermidis, Propionibacterium acnes

\section{Introduction}

Acne vulgaris is skin disorder that results of pilosebaceous follicles obstruction. Normally, it is located primarily on face and upper body [1]. The main factor involved in the pathogenesis of acne is the abnormality in colonization of normal flora including Staphylococcus aureus (S. aureus), Staphylococcus epidermidis ( $S$. epidermidis) and Propionibacterium acnes (P. acnes). S. aureus and $S$. epidermidis are gram-positive aerobic organisms. They are the opportunistic pathogens, usually involve in superficial infection within the sebaceous units [2]. For P. acnes, it is an immobile and gram-positive anaerobe that 
http://wjst.wu.ac.th

colonizes in the follicular duct. It provokes an inflammatory response by its capability to activate the bacterial enzyme (lipase) that metabolizes the sebaceous triglycerides into free fatty acids, which results in follicular wall irritation [3,4]. Generally, the common therapy for acne treatment includes topical therapy employing comedolytics and antibiotics. These comedolytics and antibiotics have several adverse effects on skin irritation, dry skin, peeling, burning, photosensitization and abnormal skin pigmentation. Moreover, the antibiotics resistance has been increasing in prevalence because of the widespread use of synthetic antibiotics in dermatological treatment [5]. Thus, the concept of applying the natural innovation to use as the anti-acne product should be considered as alternative. Even though most natural products have antimicrobial activity that is less potent than that of antibiotics, their different bactericidal actions may be capable to battle with the antibiotic-resistant bacterial strains.

Pomegranate (Punica granatum L.) is a fruit that is commonly found in various countries. All parts of this fruit can be used for remedial purposes in medical terms [6]. The phenolics in pomegranate peel extract (PPE) has demonstrated the outstanding in the anti-bacterial activity [7,8], especially the potent bacteriostatic effect against the bacteria $S$. aureus, S. epidermidis and P. acnes [8,9]. Basically, the phenolic compounds in PPE can treat through 3 main activities; anti-bacterial activity [7,9], antiinflammation [7,10] and anti-oxidation [11]. They suppress the production of substrates or the synthesis of bacteria products, which then reduce the burden of acne. To obtain the phenolic compounds from the pomegranate peel, harmful organic solvents such as methanol, acetone, ethyl acetate are commonly used [12]. The using of these organic solvents lead to environmental problems and also can cause adverse effects on health. However, the studies of Li et al. [13] and Nuamsetii et al. [14] reported that ethanolic PPE provided the notable anti-oxidant extracting efficiency using Ferric Reducing Ability of Plasma (FRAP) assay, is presented as a general method for assessing anti-oxidant power and high yield of the active total phenolic content using Folin-Ciocalteu, according to its polarity, solubility, hydrophilicity, dielectric constant. Thus, in this study we are interested in ethanolic PPE to further determine antibacterial efficacy.

However, to enhance the efficacy of the PPE for acne treatment, the design of an effective delivery device is important. Film mask is one of the dosage form that attracts our attention as it generally enhances the transport of active compounds by altering the skin barrier functions through increasing hydration of stratum corneum [15]. In addition, it is able to adhere well on the skin, while at the same time serving as a potential physical barrier against any external infection.

Nowadays, the bio-cellulose (BC) has become famous due to its exclusive ability such as high strength and flexibility, reformability, and biodegradability. $\mathrm{BC}$ is safe for its compatibility with the skin, non-toxic to cells and does not cause irritation to the skin [16]. BC is a 3D nano-sized structure, results in a large surface area for holding water soluble capacity [17]. For this reason, BC can be impregnated with aqueous solution of actives, particularly plant extracts. Because of the remarkable characteristic of the BC mentioned above, we are interested to apply the BC for acne treatment. In the present study, PPE was combined with $\mathrm{BC}$ by simple soaking. The chemical structure of the $\mathrm{BC}$ contains a plenty of a hydroxyl group, which can bind to compounds in PPE, especially phenolics comprising hydroxyl groups as well. The physical properties and the efficacy on anti-bacterial activity of the $\mathrm{BC}$ combining extract were investigated.

\section{Materials and methods}

\section{Materials}

Staphylococcus aureus (ATCC 25923), Staphylococcus epidermidis (ATCC 12228) and Propionibacterium acnes (DMST 14916) were obtained from the Department of Medical Sciences, Ministry of Public Health, National Institute of Health of Thailand. Acetobacter xylinum (TISTR107) was obtained from Thailand Institute of Scientific and Technological Research. Soyabean casein digest (SCD) agar, brain heart infusion (BHI) agar and yeast extract were purchased from HiMedia Laboratories Pvt Ltd., India. The glucose yeast extract (GYE) agar and $\mathrm{Na}_{2} \mathrm{CO}_{3}$ were purchased from Ajax Finechem, New Zealand. Gallic acid was purchased from Sigma-Aldrich, Germany. Folin-Ciocalteu's mixture solution was purchased from MERCK, Germany. L-ascorbic acid was purchased from POCH S.A., Poland. DPPH solution was purchased from Sigma-Aldrich, U.S.A. All organic solvents used are HPLC grade. 
http://wjst.wu.ac.th

\section{Plant material and preparation of the extracts}

Pomegranates ('Indian' variety) were purchased from market in Phitsanulok province, Thailand during June to August, 2015. Their peels were separated and dried in the hot air oven at a temperature of $45{ }^{\circ} \mathrm{C}$ for $72 \mathrm{~h}$. The dried peels were then blended into fine powder, sieved through 80 mesh and macerated into various solvents: water $\left(\mathrm{PPE}_{\mathrm{water}}\right), 50 \%(\mathrm{v} / \mathrm{v})\left(\mathrm{PPE}_{50 \mathrm{E}}\right), 70 \%(\mathrm{v} / \mathrm{v})\left(\mathrm{PPE}_{70 \mathrm{E}}\right)$, or $95 \%(\mathrm{v} / \mathrm{v})$ $\left(\mathrm{PPE}_{95 \mathrm{E}}\right)$ ethanol in the ratio of $1: 15(\mathrm{w} / \mathrm{v})$ of powder of dried peels/solvent at $30{ }^{\circ} \mathrm{C}$ for $24 \mathrm{~h}$ using rotary shaker (light protection). The mixtures were filtrated through Whatman No.1 filter paper. The PPE $\mathrm{water}$ was dried by lyophilization (FTS systems Dura dry, Canada), whilst the PPE $50 \mathrm{E}, \mathrm{PPE}_{70 \mathrm{E}}$ and $\mathrm{PPE}_{95 \mathrm{E}}$ were initially evaporated the ethanol using rotary evaporator, and followed by lyophilization to get the dried powder form. The obtained PPEs powder were stored at $4{ }^{\circ} \mathrm{C}$ and protected from light until used [18].

\section{Determination of total phenolic content (TPC) of the PPEs}

The TPC in PPEs was measured using Folin-Ciocalteu method [19]. Gallic in methanol at various concentrations was prepared for standard curve construction. PPEs were prepared in concentration of 1 $\mathrm{mg} / \mathrm{ml}$ in methanol. $10 \mu \mathrm{l}$ of gallic acid or PPEs at various concentrations were added into 96-well plate followed by adding $130 \mu \mathrm{l}$ of water and $10 \mu \mathrm{l}$ of Folin-Ciocalteu's mixture solution. After shaken for 5 min, $100 \mu 1$ of $7 \%(\mathrm{w} / \mathrm{v}) \mathrm{Na}_{2} \mathrm{CO}_{3}$ solution was added with mixing. The solution mixture was incubated in the dark for $30 \mathrm{~min}$ and the absorbance was measured at $750 \mathrm{~nm}$ with microplate spectrophotometer. The amount of total phenolics was calculated as gallic acid equivalents (gGAE/100g of dried peel extract) from the calibration curve. The experiment was performed in triplicate.

\section{Determination of free radical scavenging activity of the PPEs}

The screening of the free radical scavenging activity of the PPE was accomplished by using DPPH assay $[19,20]$, comparing with L-ascorbic acid. PPEs and L-ascorbic acid were dissolved at various concentrations in methanol. Seventy five $\mu \mathrm{l}$ of these dissolved samples were added into 96-well plate, followed by adding $150 \mu \mathrm{L}$ of DPPH solution $(78.8 \mu \mathrm{g} / \mathrm{ml})$. The mixture was left standing in dark for 30 min at room temperature. Then, the absorbance of the remaining of DPPH was measured by microplate spectrophotometer at wavelength of $515 \mathrm{~nm}$. Radical scavenging activity of the extracts or L-ascobic acid was expressed as the inhibition percentage (\%Rs) and calculated using the following formula (1);

$\% \mathrm{Rs}=\left[\left(\mathrm{A}_{\mathrm{c}}-\mathrm{A}_{\mathrm{s}}\right) / \mathrm{A}_{\mathrm{c}}\right] \times 100 \%$

where, Ac is the absorbance of the DPPH without the tested sample, and As is the absorbance of the $\mathrm{DPPH}$ with the tested sample. The study was expressed as mean $\pm \mathrm{SD}$. $\mathrm{IC}_{50}$, the equivalent concentration to give the $50 \%$ effect, was determined by log-probit analysis of the tested samples. The experiment was performed in triplicate. The PPE with the highest TPC and anti-oxidant activity was selected for BC combination and further determination of the anti-bacterial, stability of the BCP.

\section{Determination of anti-bacterial efficacy of the PPEs}

Fresh cultures of the isolated bacteria were maintained on SCD agar for $S$. aureus and $S$. epidermidis and $\mathrm{BHI}$ agar for P. acnes.

The minimum inhibitory concentration (MIC) of the selected PPE was determined by the microdilution assay [21]. The final inocula of bacteria; S. aureus, S. epidermidis and P. acnes were prepared in $1.5 \times 10^{5} \mathrm{CFU} / \mathrm{ml}$, using SCD broth or BHI broth medium. The PPE was prepared in an aqueous solution with various concentrations. The PPE at amount of $100 \mu \mathrm{l}$ was added into 96-well plate. Consequently, $100 \mu \mathrm{l}$ of the inoculum was added into each well, comparing with the control solution which consisted of $100 \mu \mathrm{l}$ of broth medium and $100 \mu \mathrm{l}$ of inoculum. The final concentrations of the PPE were in range of 1.9 to $1,000 \mu \mathrm{g} / \mathrm{ml}$. Blank solution was the prepared mixture of $100 \mu \mathrm{l}$ medium and 100 $\mu l$ of sterile water by without the inoculum. The cultures of $S$. aureus and $S$. epidermidis were incubated at $37{ }^{\circ} \mathrm{C}$ for $24 \mathrm{~h}$ whereas that of $P$. acnes was incubated at $37{ }^{\circ} \mathrm{C}$ for $72 \mathrm{~h}$ in anaerobic condition using anaerobic jar (OXOID, UK). Then, the samples were brought to measure the OD value at wavelength 600 
http://wjst.wu.ac.th

$\mathrm{nm}$ using microplate spectrophotometer. The study was performed in triplicate and MIC value was evaluated by calculating the percentage of inhibition ( $\% \mathrm{I})$ as followed formula (2);

$\% \mathrm{I}=\frac{\left(\left(\mathrm{T}_{\mathrm{F}} \text { Growth }-\mathrm{T}_{0} \text { Growth }\right)-\left(\mathrm{T}_{\mathrm{F}} \text { Blank }-\mathrm{T}_{0} \text { Blank }\right)\right)}{\left(\left(\mathrm{T}_{\mathrm{F}} \mathrm{PPE}-\mathrm{T}_{0} \mathrm{PPE}\right)-\left(\mathrm{T}_{\mathrm{F}} \text { Blank }-\mathrm{T}_{0} \text { Blank }\right)\right)}$

where, $\mathrm{T}_{\mathrm{F}} \mathrm{PPE}$ is the absorbance of the sample with the extract at after incubation, $\mathrm{T}_{0} \mathrm{PPE}$ is the absorbance of the sample with the extract at before incubation, $\mathrm{T}_{\mathrm{F}}$ blank is the absorbance of the blank at after incubation, $\mathrm{T}_{0}$ blank is the absorbance of the blank at before incubation, $\mathrm{T}_{\mathrm{F}}$ growth is the absorbance of the control at after incubation, and $\mathrm{T}_{0}$ growth is the absorbance of the control at before incubation.

The minimum bactericidal concentration (MBC) of the selected PPE was further determined continually to the MIC values [22] by selecting the concentration that exhibited the percentage of inhibition $(>80 \%)$ against the tested bacteria from broth dilution MIC test. The bacteria was transferred by spreading on the specific agar and incubated at $37{ }^{\circ} \mathrm{C}$ for $24 \mathrm{~h}$ for $S$. aureus and S. epidermidis and at $37{ }^{\circ} \mathrm{C}$ for $72 \mathrm{~h}$ in anaerobic condition for P. acnes. The determination of MBC value was defined as the dilution that yielded no single bacterial colony on the agar plates.

The anti-bacterial susceptibility activity was performed by disc diffusion method [21]. The suspension of the tested bacteria $\left(1.5 \times 10^{8} \mathrm{CFU} / \mathrm{ml}\right)$ was spread with the sterilized cotton stick on petri disc containing SCD agar for $S$. aureus and S. epidermidis and BHI agar for P. acnes. Consequently, 20 $\mu \mathrm{l}$ of the selected PPE that was prepared in an aqueous solution at concentrations of $1.25,2.5,5$ and 10 $\mathrm{mg} / \mathrm{ml}$ (equivalent to $11.19 \pm 0.11,22.74 \pm 0.52,28.75 \pm 0.78$ and $32.10 \pm 0.33 \mu \mathrm{g}$ of $\mathrm{TPC} / \mathrm{disc}$ ) were pipetted on the sterilized disc with the diameter of $6 \mathrm{~mm}$. Gentamicin $(2 \mu \mathrm{g} / \mathrm{disc})$ and clindamycin $(2 \mu \mathrm{g} / \mathrm{disc})$ were used as positive control for determining the sensitivity of each tested bacterial species. The inoculated plates with the extract-absorbed disc and anti-bacterial-absorbed disc were incubated at $37{ }^{\circ} \mathrm{C}$ for $24 \mathrm{~h}$ for $S$. aureus and $S$. epidermidis while $P$. acnes at $37^{\circ} \mathrm{C}$ for $72 \mathrm{~h}$ under anaerobic condition. The anti-bacterial susceptibility activity was evaluated by the measure of the clear zone diameter where the tested bacteria was not able to grow surround the disc. The study was performed in triplicate.

\section{Determination of anti-bacterial susceptibility stability of the selected PPE}

The PPE with highest TPC and anti-oxidant activity was selected for stability test. The test was performed an accelerated storage condition according to COLIPA guidelines [23] under the modified condition from the previous study at $54{ }^{\circ} \mathrm{C}$ temperature with the relative humidity (RH) of $76 \%$ for 14 days [24-26]. The tested PPE was kept in widely open glassware during the test period. Thereafter, it was prepared in various concentrations $(1.25,2.5,5$ and $10 \mathrm{mg} / \mathrm{ml})$ to determine the anti-bacterial susceptibility activity, according to the method described above, in comparison to the activity of freshly prepared PPE.

\section{Preparation of the bio-cellulose (BC) incorporating PPE (BCP)}

BC film was prepared from the culture production of bacteria A. xylinum (TISTR 107). The bacteria was separated into an individual colony by cross streak on the GYE agar containing $10 \%$ $(\mathrm{w} / \mathrm{v})$ glucose, $1 \%(\mathrm{w} / \mathrm{v})$ yeast extract, $1 \%(\mathrm{w} / \mathrm{v})$ calcium carbonate $\left(\mathrm{CaCO}_{3}\right)$ and $2 \%(\mathrm{w} / \mathrm{v})$ agar and incubated at $30{ }^{\circ} \mathrm{C}$ for 5 - 7 days. The working cultures were regularly prepared on GYE and store at $4{ }^{\circ} \mathrm{C}$ until use. The individual colonies of culture were transferred into Erlenmeyer flask containing GYE broth consisting of $10 \%(\mathrm{w} / \mathrm{v})$ glucose, $1 \%(\mathrm{w} / \mathrm{v})$ yeast extract and shaken using magnetic stirrer at $30{ }^{\circ} \mathrm{C}$ for $48 \mathrm{~h}$ to produce the slurry bacterial cellulose (SBC). The SBC were added into specific sterile container containing Hestrin and Shcramm liquid medium containing 2\% $(\mathrm{w} / \mathrm{v})$ glucose, $0.5 \%(\mathrm{w} / \mathrm{v})$ yeast extract, $0.5 \%(\mathrm{w} / \mathrm{v})$ bacto-peptone, $0.27 \%(\mathrm{w} / \mathrm{v})$ disodium phosphate and $0.115 \%(\mathrm{w} / \mathrm{v})$ citric acid and incubated at $30{ }^{\circ} \mathrm{C}$ for 14 days in the static condition. After incubation, the BC pellicle that was floating between the surface and air of the medium was collected and soaked in $0.25 \mathrm{M} \mathrm{NaOH}$ for $24 \mathrm{~h}$ to remove the excess bacteria, and the $\mathrm{BC}$ pellicle was washed thoroughly with distilled water to neutralize $\mathrm{pH}$. The worked $\mathrm{BC}$ pellicle was dried by 
http://wjst.wu.ac.th

lyophilization and protected from the moisture in desiccator before further used. The thickness of each pellicle was controlled approximately at $0.1 \mathrm{~mm}$.

To incorporate the $\mathrm{BC}$ into the selected PPE, the dried $\mathrm{BC}$ film was cut in a round-shaped in the diameter of $6 \mathrm{~mm}$ and soaked in the $1 \mathrm{ml}$ of the PPE aqueous solution $(5 \mathrm{or} 10 \mathrm{mg} / \mathrm{ml})$ at $25-30$ ${ }^{\circ} \mathrm{C}$ for $1 \mathrm{~h}$. Afterward, the soaked $\mathrm{BC}$ film was dried at $37^{\circ} \mathrm{C}$ for $2 \mathrm{~h}$ in hot air oven, The BC films incorporating with PPE (BCP) were kept away from the moisture in desiccator before used for further evaluation.

\section{Characterization of the $\mathrm{BC}$ and $\mathrm{BCP}$}

\section{$T P C$ in the $B C P$}

The $6 \mathrm{~mm}$ BCP film was impregnated in $1 \mathrm{ml}$ of distilled water at $25-30{ }^{\circ} \mathrm{C}$ for $1,5,10,15,30,60$ and $120 \mathrm{~min}$. At each time, the BCP film was removed. Then, the aqueous solution containing the released extract was determined TPC by Folin-Ciocalteu method as described above. The study was performed in triplicate.

\section{Surface morphology}

The BCs and BCPs was coated with $\mathrm{Au}^{+}$particles by cathodic spreading in a Rotary-Pumped Sputter Coater/Carbon Coater (Quorum, UK), and their surface morphology was examined under a scanning electron microscope (SEM, EDAX $\left.{ }^{\circledR}, \mathrm{USA}\right)$ with the operating at an accelerating voltage of $15 \mathrm{kV}$.

\section{Mechanical properties}

Texture analyzer (TA.XT.plus, U.K.) was used for measuring tensile strength and elongation at break of the BCs and BCPs. They were cut into rectangular shape $\left(10 \times 70 \mathrm{~mm}^{2}\right)$, and their thickness was at $0.1 \mathrm{~mm}$. The samples were clamped at the top and the end using $30 \mathrm{~kg}$ load cell. The crosshead rate set in the test was $1.00 \mathrm{~mm} \mathrm{sec}^{-1}$, and the distance between grips used was $50 \mathrm{~mm}$. At least 3 samples of BCs and BCPs in dried and wet (soaked in water for $1 \mathrm{~h}$ ) states were measured for each set. The tensile strength and elongation at break were evaluated by calculating followed formula (3) and (4);

Tensile strength $(\mathrm{MPa}) \quad=$

Breaking force

Cross-section area of sample

and

Elongation at break $(\%)=\frac{\text { Difference in length at breaking } \times 100}{\text { Original length }}$

Determination of anti-bacterial susceptibility activity of the BCP

The anti-bacterial susceptibility activity of the BCP was performed by disc diffusion method as described above and compared with that of gentamicin and clindamycin. The BCP was placed on the agar. According to determination of TPC in the BCP, we found that the TPC containing in the $6 \mathrm{~mm} \mathrm{BCP}$ prepared from soaking the BC pellicle in 5 and $10 \mathrm{mg} / \mathrm{ml}$ of the PPE aqueous solution was $89.65 \pm 27.53$ $\mu \mathrm{g}$ and $178.95 \pm 15.35 \mu \mathrm{g}$, respectively. The study was performed in triplicate.

\section{Statistical analysis}

All values were expressed as mean $\pm \mathrm{SD}$ of each group. The student's unpaired $t$-test was used to compare between each group. $P<0.05$ was considered significant difference. 
http://wjst.wu.ac.th

\section{Results and discussion}

Pomegranate peel extract (PPE) is particular interest due to its well-known anti-microbial activity. It also suggests that PPE did not exert any skin irritation [10,27]. To increase the efficacy of the extract for acne treatment, the design formulation is very important. The BC film attracts our attention because it can enhance the active delivery by changing the skin barrier function. Other advantages are: its portable packaging to be convenient to use and its single use to prevent contamination of their contents. In this study, the selected PPE with high phenolic content and anti-oxidative activity was incorporated with the $\mathrm{BC}$ film, and the persistence of the anti-microbial efficacy of the $\mathrm{BC}$ film containing the extract was determined by the disc diffusion assay.

\section{TPC and free radical scavenging activity of PPEs}

We started our work with extraction from pomegranate peel by using water or various concentrations of ethanol. The chosen solvents are based on their price and environmental benefits. The achieved PPEs were appeared with yellowish powder. The extract yield was exhibited as per $100 \mathrm{~g}$ of dried pomegranate peel, as shown in Table 1. $50 \%(\mathrm{v} / \mathrm{v})$ ethanol gave the maximum yield of the extract $\left(\mathrm{PPE}_{50 \mathrm{E}}, 34.09 \mathrm{~g} / 100 \mathrm{~g}\right.$ dried peel extract), followed by water $\left(\mathrm{PPE}_{\mathrm{water}}, 19.62 \mathrm{~g} / 100 \mathrm{~g}\right.$ dried peel extract), $70 \%(\mathrm{v} / \mathrm{v})$ ethanol (PPE $70 \mathrm{E}, 15.04 \mathrm{~g} / 100 \mathrm{~g}$ dried peel extract) and $95 \%$ (v/v) ethanol (PPE $95 \mathrm{E}, 7.54 \mathrm{~g} / 100 \mathrm{~g}$ dried peel extract), respectively. Moreover, $\mathrm{PPE}_{50 \mathrm{E}}$ had highest amount of phenolic compounds $\left(55.95 \pm 1.44 \mathrm{gGAE} / 100 \mathrm{~g}\right.$ of dried peel extract) and highest free radical scavenging activity with $\mathrm{IC}_{50}$ of $18.77 \pm 1.73 \mu \mathrm{g} / \mathrm{ml}$. L-ascorbic acid as the positive control exerted the $\mathrm{IC}_{50}$ with $4.61 \pm 0.44 \mu \mathrm{g} / \mathrm{ml}$. The large amount of phenolics in this extract may, therefore, contribute to strong anti-oxidant capacity [18]. Actually, several studies suggest that the ethanol/water solvent, particularly $50 \%(\mathrm{v} / \mathrm{v})$ ethanol is suitable to obtain the phenolics-enriched extract with broad range of polarity [28-30]. Concerning anti-oxidant activity of L-ascorbic acid, it provided a greater activity than the extracts. As phenolic anti-oxidants exhibit slow reactions to DPPH radicals whereas the potent anti-oxidant, L-ascorbic acid exerts fast reactions to the radicals [31,32]. Thus, the lower free radical scavenging activity of the extracts is possibly causes by their slow reactions to the radicals. As we known, free radicals produced by neutrophils, which are adhered to the acne lesion mediate irritation and inflammatory acne [33,34]. Therefore, minimize free radicals activity by using natural anti-oxidants would slow inflammatory progression of acne. As the obtained results, $\mathrm{PPE}_{50 \mathrm{E}}$ was selected for further determining anti-bacterial efficacy and for combining with the BC.

Table 1 Effect of solvent on \%yield, free radical scavenging activity (DPPH assay) and total phenolic content (TPC) of the pomegranate peel extracts (PPEs).

\begin{tabular}{cccc}
\hline Samples & $\begin{array}{c}\text { \%Yield } \\
(\mathbf{g} / \mathbf{1 0 0 g} \text { of dried peel extract) }\end{array}$ & $\begin{array}{c}\text { Free radical scavenging activity } \\
\text { DPPH assay }\left(\mathbf{I C}_{\mathbf{5 0}}, \boldsymbol{\mu g} \mathbf{m l}\right)\end{array}$ & $\begin{array}{c}\text { TPC } \\
\text { (gGAE/100g of dried peel extract) }\end{array}$ \\
\hline $\mathrm{PPE}_{\text {water }}$ & 19.62 & $29.65 \pm 1.00$ & $52.50 \pm 1.79$ \\
$\mathrm{PPE}_{50 \mathrm{E}}$ & 34.09 & $18.77 \pm 1.73$ & $55.95 \pm 1.44$ \\
$\mathrm{PPE}_{70 \mathrm{E}}$ & 15.04 & $33.80 \pm 2.17$ & $48.00 \pm 1.17$ \\
$\mathrm{PPE}_{95 \mathrm{E}}$ & 7.54 & $75.80 \pm 5.00$ & $45.04 \pm 1.16$ \\
$\mathrm{~L}$-ascorbic acid & - & $4.61 \pm 0.44$ & - \\
\hline
\end{tabular}

${ }^{*} \mathrm{PPE}_{\mathrm{water}}, \mathrm{PPE}_{50 \mathrm{E}}, \mathrm{PPE}_{70 \mathrm{E}}$ and $\mathrm{PPE} 95 \mathrm{E}$ are the pomegranate peel extracted from water, $50 \%$ (v/v), $70 \%(\mathrm{v} / \mathrm{v})$ and $95 \%$ $(\mathrm{v} / \mathrm{v})$ ethanol, respectively. 
http://wjst.wu.ac.th

\section{Anti-bacterial efficacy of the PPEs}

As $\mathrm{PPE}_{50 \mathrm{E}}$ had the highest yield and anti-oxidant capacity, it was selected for determining antimicrobial activity and for combining with the BC. MIC and MBC values of PPE $\mathrm{SEE}_{5}$ are shown in Table 2. $\mathrm{PPE}_{50 \mathrm{E}}$ was effective against $S$. aureus, $S$. epidermidis (MIC value, $500 \mu \mathrm{g} / \mathrm{ml}$ ) and $P$. acnes (MIC value, $1,000 \mu \mathrm{g} / \mathrm{ml}$ ). In addition, $\mathrm{PPE}_{50 \mathrm{E}}$ gave the $\mathrm{MBC}$ value against $S$. aureus and $S$. epidermidis at the value of $1,000 \mu \mathrm{g} / \mathrm{ml}$ whilst exhibited $\mathrm{MBC}$ value $>1,000 \mu \mathrm{g} / \mathrm{ml}$ against $P$. acnes. In this experiment, the highest concentration of PPE used was $1,000 \mu \mathrm{g} / \mathrm{ml}$. This is because of the limitation of the $\mathrm{PPE}_{50}$ solubility in the broth medium. For anti-microbial activity, $\mathrm{PPE}_{50 \mathrm{E}}$ exerted the activity of bactericidal against $S$. aureus (ATCC 25923), S. epidermidis (ATCC 12228) and P. acnes (DMST 14916) as bactericidal activity has been defined as a ratio of MBC to MIC of $>4[35,36]$. The obtained results coincide with the previous studies indicating susceptibility of pomegranate peel extract to $S$. aureus, $S$. epidermidis and $P$. acnes [7,37-40]. Moreover, there has been report about an effectiveness of ethanolic extracts of pomegranate peel to inhibit methicillin-resistant Staphylococcus aureus (MRSA) strain $[40,41]$. The results from our present study, coupled with the results from other groups, indicate the potential of $\mathrm{PPE}_{50 \mathrm{E}}$ as an alternative for acne treatment.

Table 2 Minimum inhibitory concentration (MIC) and minimum bactericidal concentration (MBC) of $\mathrm{PPE}_{50}$ against $S$. aureus, $S$. epidermidis and $P$. acnes.

\begin{tabular}{lcc}
\hline \multicolumn{1}{c}{ Microorganism } & MIC $(\boldsymbol{\mu g} / \mathbf{m l})$ & MBC $(\boldsymbol{\mu g} / \mathbf{m l})$ \\
\hline S. aureus (ATCC 25923) & 500 & 1,000 \\
S. epidermidis (ATCC 12228) & 500 & 1,000 \\
P. acnes (DMST 14916) & 1,000 & $>1,000$ \\
\hline
\end{tabular}

An example of inhibition zone of $\mathrm{PPE}_{50}$ is shown in Figures 1(a) and 1(b) shows that $\mathrm{PPE}_{50 \mathrm{E}}$ at the concentrations of 1.25 (equivalent to $11.19 \pm 0.11 \mu \mathrm{g}$ of TPC/disc), 2.5 (equivalent to $22.74 \pm 0.52 \mu \mathrm{g}$ of $\mathrm{TPC} / \mathrm{disc}$ ), 5 (equivalent to $28.75 \pm 0.78 \mu \mathrm{g}$ of TPC/disc) and $10 \mathrm{mg} / \mathrm{ml}$ (equivalent to $32.10 \pm 0.33 \mu \mathrm{g}$ of TPC/disc) exhibited the inhibition zone, which was about 2 to 5 times larger than the original disc diameter as a dose-dependent manner. At the concentration of $10 \mathrm{mg} / \mathrm{ml}, \mathrm{PPE}_{50 \mathrm{E}}$ presented highest potential to inhibit $S$. aureus (diameter of clear zone, $21.0 \pm 1.00 \mathrm{~mm}$ ) and $S$. epidermidis (diameter of clear zone, $23.7 \pm 0.58 \mathrm{~mm}$ ) nearly by $2 \mu \mathrm{g}$ of gentamicin (diameter of clear zone, $21.3 \pm 0.58$ for $S$. aureus and $24.3 \pm 0.58 \mathrm{~mm}$ for $S$. epidermidis). Additionally, $\mathrm{PPE}_{50 \mathrm{E}}$ at this concentration exhibited highest inhibitory activity against the $P$. acnes (diameter of clear zone, $35.0 \pm 1.00 \mathrm{~mm}$ ) whereas $2 \mu \mathrm{g}$ of clindamycin exerted the diameter of clear zone with $45.0 \pm 1.00 \mathrm{~mm}$. Subsequently accelerated stability test was performed under the modified conditions following the temperature of $54{ }^{\circ} \mathrm{C}$ with the $\mathrm{RH}$ of 76 $\%$ for 14 days. The TPC of PPE ${ }_{50 \mathrm{E}}$ tended to be smaller but not significantly different when compared to the TPC of the freshly prepared $\mathrm{PPE}_{50 \mathrm{E}}(31.95 \mu \mathrm{g}$ of TPC/disc $)$. The inhibition zone of $\mathrm{PPE}_{50 \mathrm{E}}$ against the tested bacteria was still 2 to 5 times larger diameter of the disc. However, such inhibition zone was significantly smaller when compared with that of the freshly prepared $\mathrm{PPE}_{50 \mathrm{E}}$ except the zone of $S$. aureus and $S$. epidermidis inhibition by $10 \mathrm{mg} / \mathrm{ml}$ of $\mathrm{PPE}_{50 \mathrm{E}}$ and of $P$. acnes inhibition by 5 and $10 \mathrm{mg} / \mathrm{ml} \mathrm{of}$ $\mathrm{PPE}_{50 \mathrm{E}}$, which were no significant difference between at freshly prepared and after stability test. Although, the TPC and anti-microbial activity of $\mathrm{PPE}_{50 \mathrm{E}}$ was decreased after stability test, the great susceptibility of the tested bacteria to $\mathrm{PPE}_{50 \mathrm{E}}$ was still observed, particularly $\mathrm{PPE}_{50 \mathrm{E}}$ at high concentrations (5 and 10 $\mathrm{mg} / \mathrm{ml})$. To prolong its anti-microbial activity, therefore, the $\mathrm{PPE}_{50 \mathrm{E}}$ should be kept in the dried state by storage in tight containers at room temperature and protected from moisture. Therefore, the $\mathrm{PPE}_{50 \mathrm{E}}$ at concentrations of 5 and $10 \mathrm{mg} / \mathrm{ml}$ was selected for combining with the BC. 
http://wjst.wu.ac.th

(a)

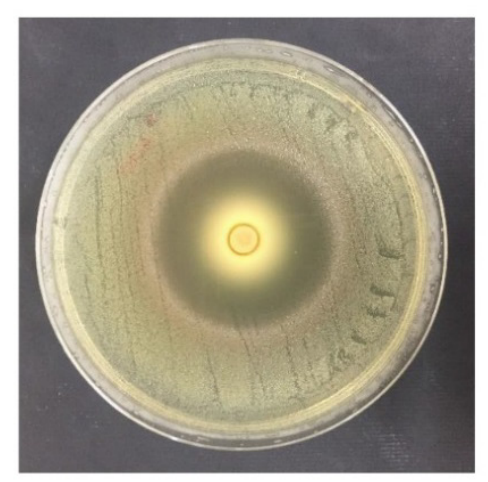

(b)

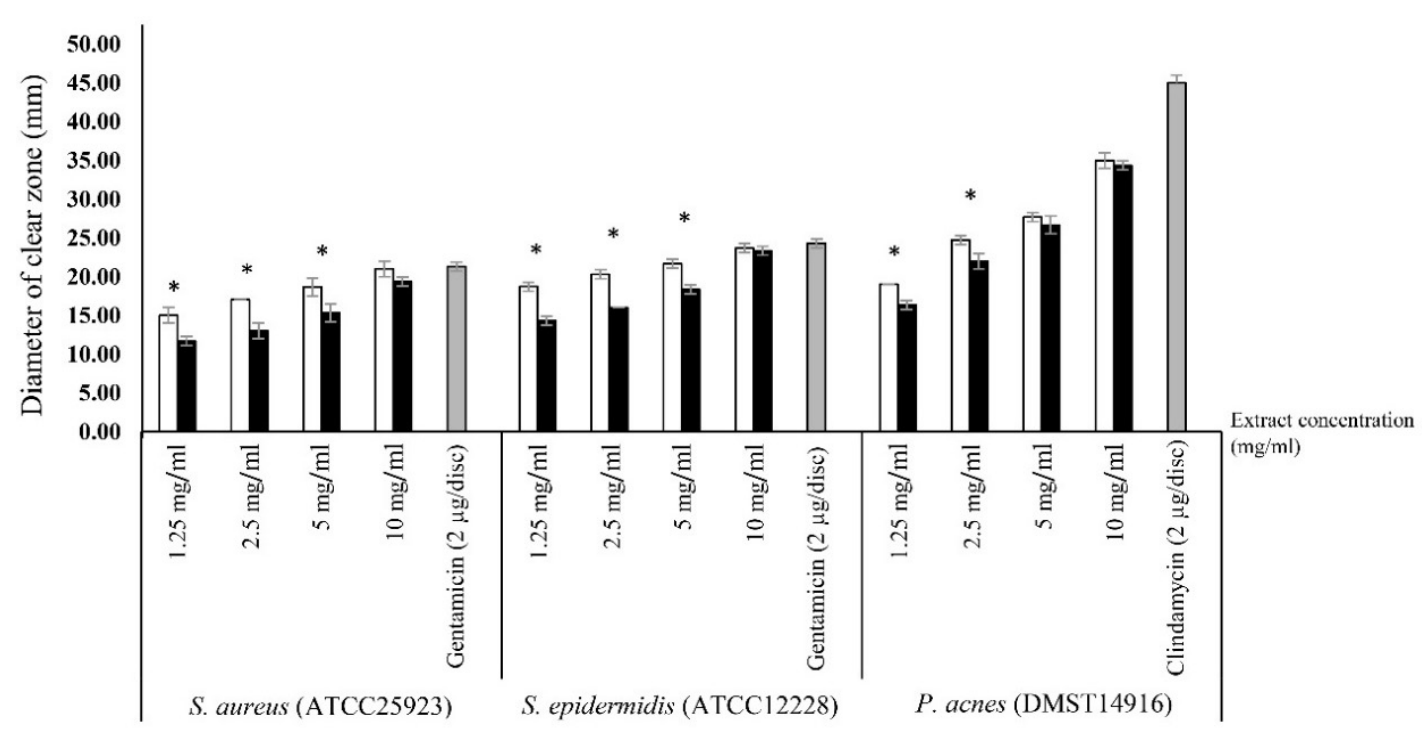

Figure 1 An example of inhibition zone of $\mathrm{PPE}_{50}$ at concentration of $10 \mathrm{mg} \mathrm{ml}^{-1}$ against $P$. acnes (a), and the diameter of clear zone of various concentrations of $\mathrm{PPE}_{50}(\mathrm{~b})$, which was at freshly prepared (light bar) and after stability test (dark bar) against S. aureus, S. epidermidis and P. acnes. Each bar represents mean $\pm \mathrm{SD}$ of diameter of zone of inhibition including disc diameter of $6 \mathrm{~mm} .{ }^{*} p<0.05$, when compared between each group ( $\mathrm{n}=3$, Student's $t$-test).

\section{Characteristics of $\mathrm{BC}$ and $\mathrm{BCP}$}

The $\mathrm{BC}$ film prepared from the culture production of bacteria A. xylinum was a strong film with the tensile strength in range of $5-15 \mathrm{MPa}$ and the elongation at break about $5 \%$ [42]. The simple soaking method was used to combine $\mathrm{BC}$ with $\mathrm{PPE}_{50 \mathrm{E}}$. After, immersing in $1 \mathrm{ml}$ of distilled water, the cumulative amount of the extract released from the $6 \mathrm{~mm} \mathrm{BCP} \mathrm{film} \mathrm{was} \mathrm{determined} \mathrm{as} \mathrm{TPC.} \mathrm{We} \mathrm{found}$ that the TPC value was relatively constant after $60 \mathrm{~min}$ of the study. For the BCP prepared by soaking the $\mathrm{BC}$ in $5 \mathrm{mg} / \mathrm{ml}$ of $\mathrm{PPE}_{50 \mathrm{E}}$, TPC determined at $1 \mathrm{~h}$ of the study was $89.69 \pm 27.53 \mu \mathrm{g}$ while that prepared by soaking the $\mathrm{BC}$ in $10 \mathrm{mg} / \mathrm{ml}$ of $\mathrm{PPE}_{50 \mathrm{E}}$ was $178.95 \pm 15.35 \mu \mathrm{g}$. 
The physical appearance of dried BC and BCP films are shown in Figure 2. After lyophilization of the pellicle, the obtained $\mathrm{BC}$ was a flexible white film and uniformity with a thickness of $0.1 \mathrm{~mm}$. The BCP was appeared with flexible and yellowish film which according to the colour of the extract itself.
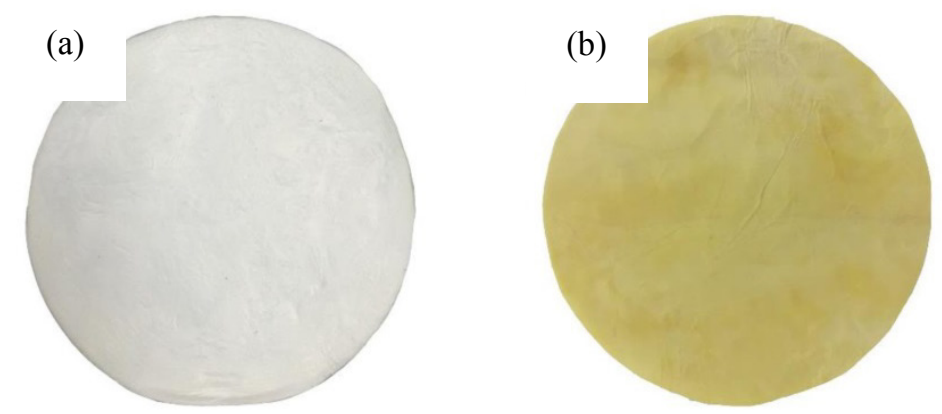

Figure 2 Physical appearance of the dried BC dried (a) and BPC (b).

By the SEM, the assemble nano-fibrils and the layer structure of the BC was found. Figures 3(a) and 3(b) demonstrates the surface morphology of $\mathrm{BC}$ and $\mathrm{BCP}$, such layer structure resulted from curling and interweaving the nano-fibrils into a 3-D interconnecting pores. Focusing on the BCP, the closer compaction of the fibrils and the absorption of the extract components on the fibrils were found. Figures 3(c) and 3(d) illustrates the cross-sectional view of BC and BCP which possessed multiple layers structure. The fibril structure and the interconnecting pores of the $\mathrm{BC}$ influence on its absorption ability and mechanical properties including tensile strength and elasticity (percent elongation at break) value $[43,45]$.
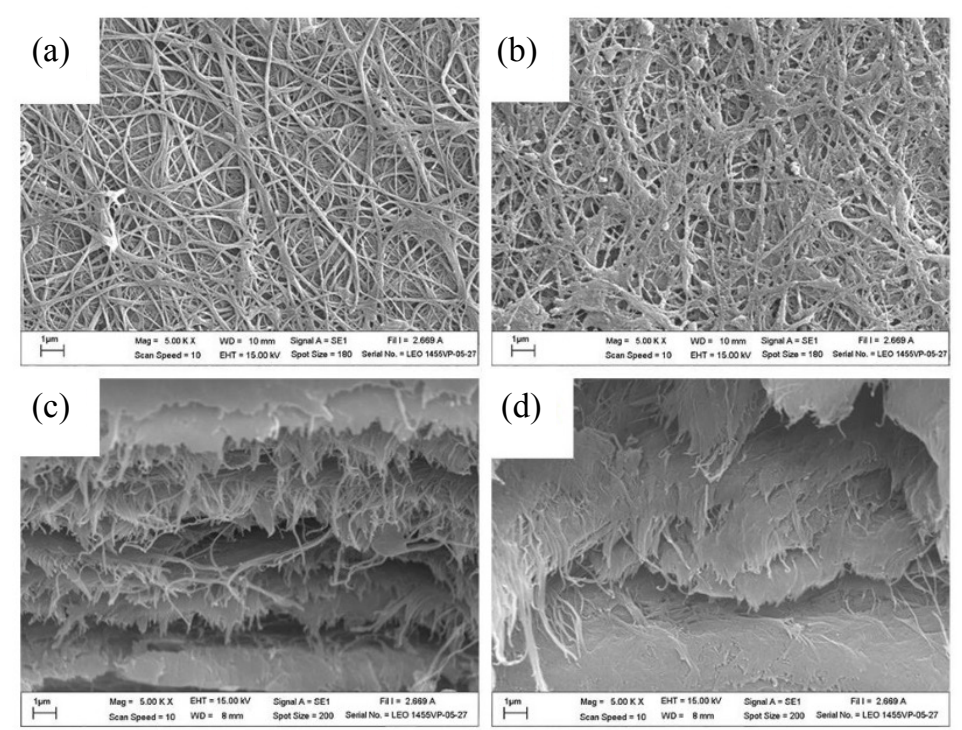

Figure 3 Surface photomicrographs of BC (a) and BCP (b), and cross-sectional photomicrographs of BC (c) and BCP (d).

The mechanical properties of the dried BC and BPC are shown in Figure 4. The dried BPC film (tensile strength, 11.22 $\pm 0.75 \mathrm{MPa}$; elongation at break, $2.16 \pm 0.68 \%$ ) showed higher tensile strength value but lesser percent elongation at break value than the dried BC film (tensile strength, 5.91 \pm 0.79 
$\mathrm{MPa}$; elongation at break, $4.95 \pm 0.58 \%$ ), which indicate more toughness of the BCP film compared with the $\mathrm{BC}$ film. The closer compaction found caused from the absorption of the extract components on the fibrils through the interactions between the hydroxyl groups of the phenolics contained in the extract and the hydroxyl groups of the BC. The mechanical properties of BC and BPC after being saturated with water (wet state) were also observed. Both wet BC and BPC could retain their shape. However, when compare to the dried film, the wet film showed an increase in percent elongation at break (BC, $14.47 \pm 1.74 \%$; BPC, $13.58 \pm 2.63 \%$ ) and a decrease in tensile strength (BC, $2.61 \pm 0.93 \mathrm{MPa}$; BPC, $5.86 \pm 0.29 \mathrm{MPa})$, which indicate more soft and flexible film were observed after the $\mathrm{BC}$ and $\mathrm{BCP}$ films were immersed in the water (wet state). The release of the extract components from the BCP and/or the absorption of the water by the BC may increase the porous formation of the fibril network, consequently enhance the flexibility of the wet films. The softness and flexibility of the wet film indicate that the BCP should be applied on the wet or moist skin (after washing).

(a)

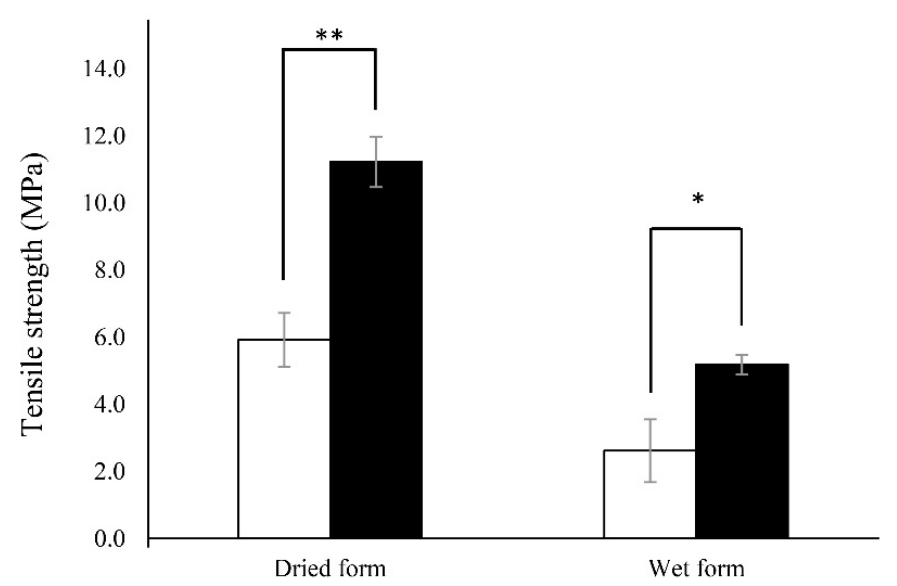

(b)

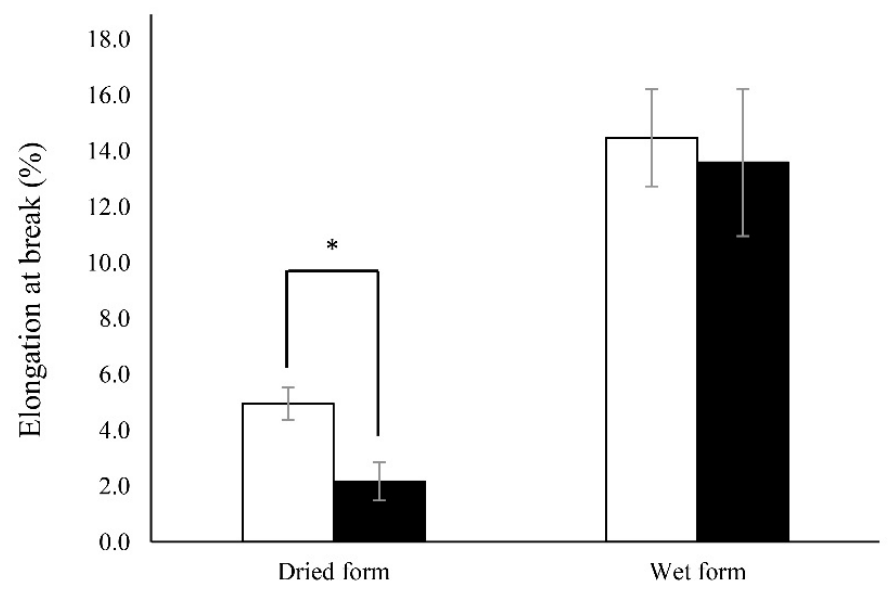

Figure 4 Tensile strength (a) and percent elongation at break (b) of the BC (light bar) and BCP (dark bar) at dried and wet state. Each bar represents mean $\pm \mathrm{SD}$ of triplicate study. ${ }^{*} p<0.05,{ }^{* *} p<0.01$, when compared between each group $(\mathrm{n}=3$, Student's $t$-test $)$. 


\section{Anti-bacterial susceptibility activity of the BCP}

The BCP films prepared by soaking the BC in 5 or $10 \mathrm{mg} / \mathrm{ml}$ of PPE $50 \mathrm{E}$ showed high TPC released after they were immersed in water for $1 \mathrm{~h}$. This indicates high absorption capacity of the $\mathrm{BC}$ to the extract components. The persistence of the anti-bacterial efficacy of the extract against $S$. aureus, S. epidermidis and $P$. acnes was observed, according to the disc diffusion assay of the BCP. Figure 5(a) shows an example of inhibition zone of the $6 \mathrm{~mm} \mathrm{BCP}$, which was prepared by soaking the $\mathrm{BC}$ in $10 \mathrm{mg} / \mathrm{ml} \mathrm{of}$ $\mathrm{PPE}_{50 \mathrm{E}}$ against $P$. acnes, and the clear zone diameter of the BCP prepared from 5 and $10 \mathrm{mg} / \mathrm{ml}$ of PPE $50 \mathrm{E}$ is shown in Figure 5(b). Both BCP formula exerted anti-bacterial activity against S. aureus, $S$. epidermidis and $P$. acnes. The inhibition zones of the BCP were 2 to 5 times larger than the original diameter of disc and even closed to those of gentamycin and clindamycin. This implies that the antibacterial components of the extract could be released from the film and showed the activity.

(a)

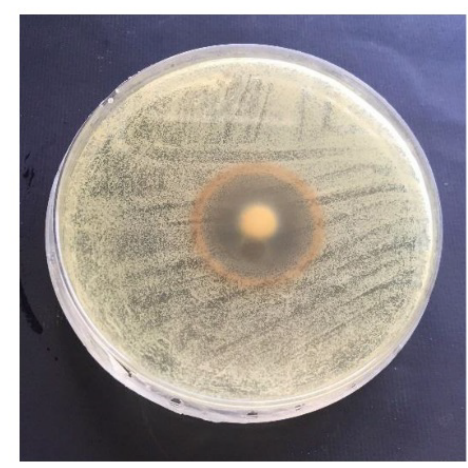

(b)

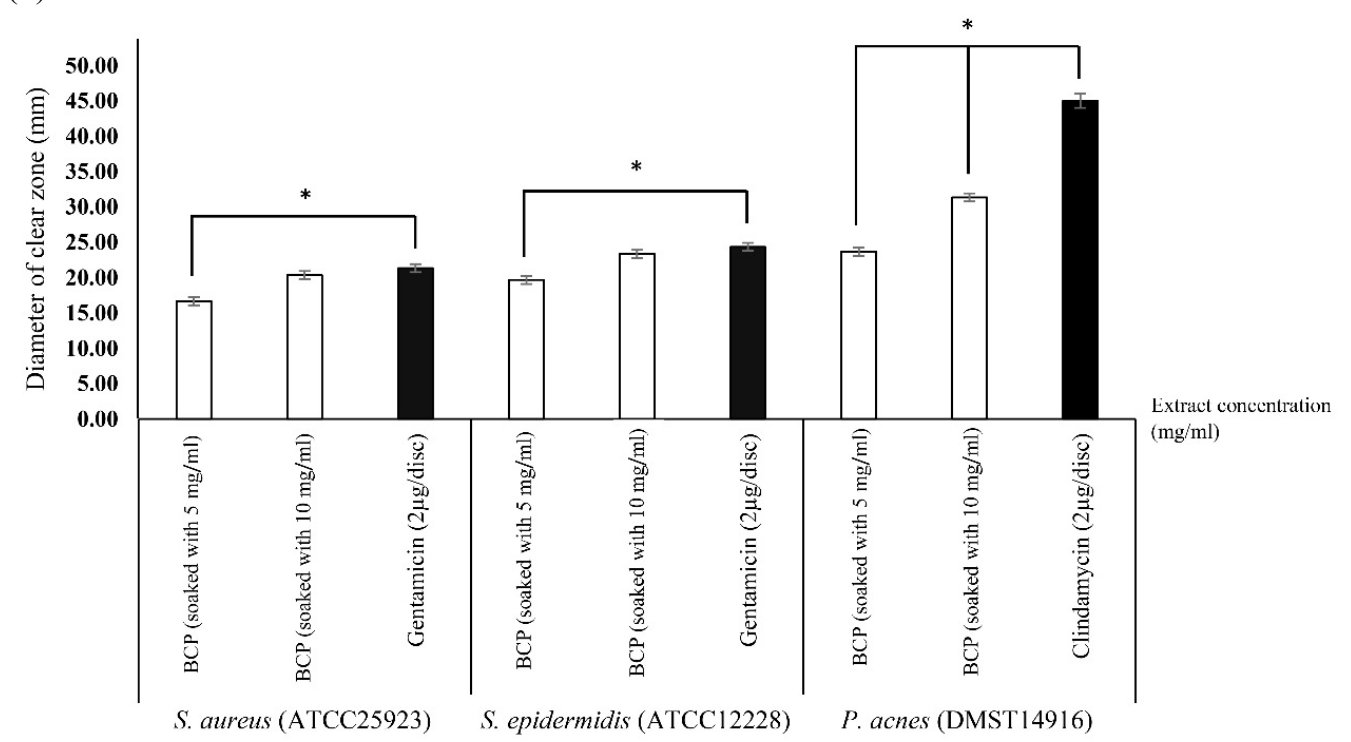

Figure 5 An example of inhibition zone of the BCP at concentration of $10 \mathrm{mg} \mathrm{ml}^{-1}$ against P. acnes (a), and the diameter of clear zone of the BCP (b), which was prepared by soaking the $6 \mathrm{~mm} \mathrm{BC}$ film in 5 or $10 \mathrm{mg} \mathrm{ml}^{-1}$ of PPE50 against $S$. aureus, S. epidermidis and P. acnes. Each bar represents mean \pm SD of diameter of zone of inhibition including disc diameter of 6-mm. $* p<0.05$, when compared to the positive control ( $\mathrm{n}=3$, Student's $t$-test). 
http://wjst.wu.ac.th

In fact, the components of the $\mathrm{PPE}_{50 \mathrm{E}}$ determined in this study have broad range of polarity. They are able to deposit into stratum corneum (hydrophobic) where $S$. aureus and $S$. epidermidis usually reside and also penetrate into deeper layer of skin (hydrophilic) and sebaceous gland (hydrophobic) where $P$. acnes resides. The occlusive effect of the $\mathrm{BC}$ film would enhance the penetration of the extract components in the infected pilosebaceous unit.

\section{Conclusions}

In this study, $\mathrm{PPE}_{50 \mathrm{E}}$ exhibited the highest \%yield, TPC and anti-oxidant activity as compared to the other extracts. S. aureus, $S$. epidermidis and P. acnes showed high susceptibility to the $\mathrm{PPE}_{50 \mathrm{E}}$. The $\mathrm{PPE}_{50 \mathrm{E}}$ had also rather good stability, in term of anti-bacterial efficacy. The BCP prepared from combining between the bio-cellulose and $\mathrm{PPE}_{50 \mathrm{E}}$ at concentrations of 5 or $10 \mathrm{mg} / \mathrm{ml}$ provided the tough nano-fibril film and possessed a satisfactory inhibition effect on $S$. aureus, $S$. epidermidis and $P$. acne compared to gentamicin and clindamycin. From the remarkable characteristics of the $\mathrm{BCP}$ in the capability of mechanical properties along with the bacterial inhibition, which is the interestingly alternative device for anti-acne.

\section{Acknowledgements}

We would like to thank Naresuan University for financial support for graduate student. We also thank the Center of Excellence for Innovation in Chemistry (PERCH-CIC), Office of the Higher Education Commission and the Faculty of Pharmaceutical Sciences, Naresuan University for facility supports.

\section{References}

[1] JJ Leyden. Therapy for acne vulgaris. N. Engl. J. Med. 1997; 16, 1156-62.

[2] AP Desbois and KC Lawlor. Antibacterial activity of long-chain polyunsaturated fatty acids against Propionibacterium acnes and Staphylococcus aureus. Mar. Drugs 2013; 11, 4544-57.

[3] G Sibi. Inhibition of lipase and inflammatory mediators by Chlorella lipid extracts for anti-acne treatment. J. Adv. Pharm. Tech. Res. 2015; 6, 7-12.

[4] V Patil, A Bandivadekart and D Debjani. Inhibition of Propionibacterium acnes lipase by extracts of Indian medicinal plants. Int. J. Cosmet. Sci. 2012; 34, 234-9.

[5] A Andriessen and CW Lynde. Antibiotic resistance: Shifting the paradigm in topical acne treatment. J. Drugs. Dermatol. 2014; 13, 1358-64.

[6] A Zarfeshany, S Asgary and SH Javanmard. Potent health effects of pomegranate. Adv. Biomed. Res. 2014; 3, 100.

[7] P Panichayupakaranant, S Tewtrakul and S Yuenyongsawad. Antibacterial, anti-inflammatory and anti-allergic activities of standardised pomegranate rind extract. Food Chem. 2010; 2, 400-3.

[8] A Scalbert. Antimicrobial properties of tannins. Phytochemistry 1991; 12, 3875-83.

[9] Z Li, PH Summanen, J Downes, K Corbett, T Komoriya, SM Henning, J Kim and SM Finegold. Antimicrobial activity of pomegranate and green tea extract on Propionibacterium acnes, Propionibacterium granulosum, Staphylococcus aureus, Staphylococcus epidermidis. J. Drugs Dermatol. 2015; 14, 574-8.

[10] CJ Lee, LG Chen, WL Liang and CC Wang. Multiple activities of Punica granatum Linne against acne vulgaris. Int. J. Mol. Sci. 2017; 18, 141.

[11] S Malviya, Arvind, A Jha and N Hettiarachchy. Anti-oxidant and antibacterial potential of pomegranate peel extracts. J. Food Sci. Tech. 2014; 51, 4132-7.

[12] PS Negi and GK Jayaprakasha. Anti-oxidant and antibacterial activities of Punica granatum peel extracts. J. Food Sci. 2003; 684, 1473-7.

[13] Y Li, C Guo, J Yang, J Wei, J Xu and S Cheng. Evaluation of anti-oxidant properties of pomegranate peel extract in comparison with pomegranate pulp extract. Food Chem. 2006; 96, 25460. 
http://wjst.wu.ac.th

[14] T Nuamsetti, P Dechayuenyong and S Tantipaibulvut. Antibacterial activity of pomegranate fruit peels and arils. ScienceAsia 2012; 38, 319-22.

[15] H Zhai and HI Maibach. Occlusion vs. skin barrier function. Skin Res. Tech. 2002; 8, 1-6.

[16] FG Torres, S Commeaux and OP Troncoso. Biocompatibility of bacterial cellulose based biomaterials. J. Funct. Biomater. 2012; 3, 864-78.

[17] N Lin and A Dufresne. Nanocellulose in biomedicine: Current status and future prospect. Eur. Polym. J. 2014; 59, 302-25.

[18] Z Wang, Z Pan, H Ma and GG Atungulu. Extract of phenolics from pomegranate peels. Open Food. Sci. J. 2011; 5, 17-25.

[19] J Viyoch, K Mahingsa and K Ingkaninan. Effects of Thai Musa species on prevention of UVBinduced skin damage in mice. Food Chem Toxicol. 2012; 50, 4292-301.

[20] K Itsarasook, K Ingkaninan and J Viyoch. Artocarpin-enriched extract reverses collagen metabolism in UV-exposed fibroblasts. Biologia 2014; 69, 943-51.

[21] J Viyoch, N Pisutthanan, A Faikreua, K Nupangta, K Wangtorpol and J Ngokkuen. Evaluation of in vitro antimicrobial activity of Thai basil oils and their micro-emulsion formulas against Propionibacterium acnes. Int. J. Cos. Sci. 2006; 28, 125-33.

[22] SG Jenkins and AN Schuetz. Current concept in laboratory testing to guide antimicrobial therapy. Mayo. Clin. Proc. 2012; 87, 290-308.

[23] COLIPA. The European Cosmetics Association, Guidelines on Stability Testing of Cosmetic Products. 2004.

[24] RP Vieira, AR Fernandes, TM Kaneko, VO Consiglieri, CASdO Pinto, CSC Pereira, AR Baby and MVR Velasco. Physical and physicochemical stability evaluation of cosmetic formulations containing soybean extract fermented by Bifidobacterium animalis. Braz. J. Pharm. Sci. 2009; 45, 515-25.

[25] D Lerche and T Sobisch. Direct and accelerated characterization of formulation stability. J. Disp. Sci. Tech. 2011; 32, 1799-811.

[26] MC Cláudio, LAdOSilva, JG Amaral and MF Leite. Development, characterization and stability study of nanometric systems containing hydrogen peroxide for dental bleaching. Int. J. Pharm. Sci. Res. 2017; 8, 4551-64.

[27] A Vidal, A Fallarero, BR Peña, ME Medina, B Gra, F Rivera, Y Gutierrez and PM Vuorela. Studies on the toxicity of Punica granatum L. (Punicaceae) whole fruit extracts. J. Ethnopharmacol. 2003; 89, 295-300.

[28] J Viyoch, K Mahingsa and K Ingkaninan. Effects of Thai Musa species on prevention of UVBinduced skin damage in mice. Food. Chem. Toxicol. 2012; 50, 4292-301.

[29] QD Do, AE Angkawijaya, PL Tran-Nguyen, LH Huynh, FE Soetaredjo, S Ismadji and YH Ju. Effect of extraction solvent on total phenol content, total flavonoid content, and anti-oxidant activity of Limnophila aromatica. J. Food. Drug. Anal. 2014; 22, 296-302.

[30] M Alothman, R Bhat and AA Karim. Anti-oxidant capacity and phenolic content of selected tropical fruits from Malaysia, extracted with different solvents. Food. Chem. 2009; 115, 785-8.

[31] D Babu, P Gurumurthy, SK Borra and KM Cherian. Anti-oxidant and free radical scavenging activity of triphala determined by using different in vitro models. J. Med. Plants. Res. 2013; 7, 2898905.

[32] K Mitra and N Uddin. Total phenolics, flavonoids, proanthrocyanidins, ascorbic acid contents and in vitro anti-oxidant activities of newly developed isolated soya protein. Dis. J. Agri. Food. Sci. 2014; 2, 160-8.

[33] $\mathrm{OH}$ Mills, MC Criscito, TE Schlesinger, R Verdicchio and E Szoke. Addressing free radical oxidation in acne vulgaris. J. Clin. Aesthet. Dermatol. 2016; 9, 25-30.

[34] S Briganti and M Picardo. Anti-oxidant activity, lipid peroxidation and skin diseases: What's new? J. Eur. Acad. Dermatol. Venereol. 2003; 17, 663-39.

[35] PR Murray and JH Jorgensen. Quantitative susceptibility test methods in major United States medical centers. Antimicrob. Agents Chemother. 1981; 20, 66-70. 
[36] LR Peterson and CJ Shanholtzer. Tests for bactericidal effects of antimicrobial agents: Technical performance and clinical relevance. Clin. Microbiol. Rev. 1992; 5, 420-32.

[37] B Gullon, ME Pintado, JA Pérez-Álvarez and M Viuda-Martos. Assessment of polyphenolic profile and antibacterial activity of pomegranate peel (Punica granatum) flour obtained from co-product of juice extraction. Food. Control. 2016; 59, 94-8.

[38] C Pagliarulo, Vd Vito, G Picariello, R Colicchio, G Pastore, P Salvatore and MG Volpe. Inhibitory effect of pomegranate (Punica granatum L.) polyphenol extracts on the bacterial growth and survival of clinical isolates of pathogenic Staphylococcus aureus and Escherichia coli. Food. Chem. 2016; 190, 824-31.

[39] S Abdollahzadeh, RY Mashouf, H Mortazavi, MH Moghaddam, N Roozbahani and M Vahedi. Antibacterial and antifungal activities of Punica granatum peel extracts against oral pathogens. $J$. Dent. 2011; 8, 1-6.

[40] X Su, AB Howell and DH D'Souza. Antibacterial effects of plant-derived extracts on methicillinresistant Staphylococcus aureus. Foodborne. Pathog. Dis. 2012; 9, 573-8.

[41] NS Al-Zoreky. Antimicrobial activity of pomegranate (Punica granatum L.) fruit peels. Int. J. Food Microbiol. 2009; 134, 244-8.

[42] S Yamanaka and K Watanabe. Applications of Bacterial Cellulose. In: RD Gilbert (ed.). Cellulosic Polymers: Blends and Composites. Hanser Publishers, New York, 1994, p. 207-15.

[43] ST Schrecker and PA Gostomski. Determining the water holding capacity of microbial cellulose. Biotechnol. Lett. 2005; 27, 1435-8.

[44] M Iguchi, S Yamanaka and A Budhiono. Bacterial cellulose: A masterpiece of nature's arts. J. Mater. Sci. 2000; 35, 261-70.

[45] M Phisalaphong, T Suwanmajo and P Tammarate. Synthesis and characterization of bacterial cellulose/alginate blend membranes. J. Appl. Polym. Sci. 2008; 107, 3419-24. 